\title{
Entrepreneurial Journey: Emergence from Entrepreneurial Intent to Opportunity Realization
}

\author{
Min-Seok Cha, Zong-Tae Bae \\ KAIST Graduate School of Management, Dongdaemun-gu, Seoul, Korea
}

\begin{abstract}
Entrepreneurial journey of new business creation starts when a business opportunity is discovered by nascent entrepreneurs. There are many obstacles along the journey, and must be an 'internal driving force' to create entrepreneurial actions for problem solving.

This paper develops a new concept of 'entrepreneurial intent' as an internal driving force of opportunity realization with 'drive' (sense of crisis) and 'directivity' (sense of opportunity). Furthermore, it presents a theory of the underlying entrepreneurial process with entrepreneurial intent. Case study methods and grounded theory building are utilized.

The results based on cases from high-tech venture firms in Korea show that entrepreneurial intent toward a new opportunity is emerged to collective actions for combining new resources to create new values. The entrepreneurial intent is the extreme level of achievement motivation which is comprised of arousal, direction, and duration (reducing the cognition gap), and drives $3 \mathrm{C}$ effects such as 'channeling', 'concentrating' and 'continuing' of entrepreneurial actions. The entrepreneurial actions, in turn, make more chances of serendipity in the external process of networking and gaining resources (reducing the resource gap), and the internal process of value creation. Value creation finally converts discovered opportunities into realized opportunities to complete the entrepreneurial journey.
\end{abstract}

\section{INTRODUCTION}

In the course of opportunity realization, entrepreneurs create new ventures from scratch. The interaction of entrepreneur and opportunity is the essence of entrepreneurship, while no distinctive theory explains it [30]. Opportunity is the potential state of value creation, and is realized through the emergent process [26]. Emergence means that entrepreneurs interact with other economic agents which have resources to create a new venture that can deliver values in the marketplace.

Entrepreneurship is the innovative process, because entrepreneurs should create new technological solutions, products and services. Innovation is the uncertain journey [36][38]. Entrepreneurs can fail many times in their journey of new business creation. New ventures confront a number of diverse problems, pitfalls, and obstacles. Although the dominant problems like new product development and commercialization are predictable [20], the real problems are diverse and numerous. Entrepreneurs try to solve these problems throughout the new venture creation process. So we call it an 'entrepreneurial journey' not a 'predictable sprint.'

Moreover, a new venture experiences the 'liability of newness' [33]. Initial conditions such as asset, network, legitimacy, and capability are disadvantageous to the new organizations. Moreover, there come newly emerged problems and events to cope with. Lack of resources and legitimacy cannot guarantee the competitive advantage of new entrants [4]. The traditional resource based view hardly explains the future of the new ventures. However, the concept of an 'entrepreneurial capability' has been suggested to develop a theory in entrepreneurship. Entrepreneurial capability is the capability to combine new resources that will have new values in the future market [2][3].

The next step of research is directed to the mechanism of new resource combination or the entrepreneurial process. The generative mechanism of an entrepreneurial process [9] cannot be easily identified through the existing methods of survey. The phenomenon of entrepreneurship is emergent [26], that is the interaction of agents and circumstances. Basically the new intentionality of implementing idea seems to drive the process of organizing and commercializing $[1][10][19]$. Entrepreneurs say that strong intent is requisite in the process of new business creation [25]. We should shed light on the process within the black box. The mechanism of intentionality, that is a least known part in the entrepreneurial process [23], should be studied and revealed.

Although the nexus of entrepreneurs and an opportunity is the key of entrepreneurship [30], the focal point of research in the field has faded away from the entrepreneur oneself. That partially stems from the failure of early research on personality factors in explaining the phenomenon consistently. This attempt of theory building research takes the advice of 'accommodating a person and a process' at the same time [31].

The entrepreneurial process can be viewed as the nexus of entrepreneur and opportunity. The cause and the generative mechanism of entrepreneurial process is obsessively dealt with in the process of theory building and validating. The clue of cause is the 'strong intent' and the generative mechanism of new resources should start from the characteristics of 'emergence.' This paper wants to answer the following questions:

1) What are the internal driving forces of the entrepreneurial process?

2) How do they drive the entrepreneurial process to realize new opportunities?

Theoretical foundation is built upon the existing literature. In this paper, theory building process is grounded in multiple cases and the entrepreneurial journey is explored with them.

\section{LITERATURE REVIEW}

The focal point of our theory development is the entrepreneurial process with interactions between 


\section{PICMET 2008 Proceedings, 27-31 July, Cape Town, South Africa (c) 2008 PICMET}

entrepreneurs and opportunities. Although many studies on the characteristics of entrepreneurs show the diverse results, some topics on the features of entrepreneurs, their choices and behavioral orientations still have values and importance [11][24][31]. We provide a review of several theoretical perspectives and notions that help us develop a theory of entrepreneurial intent, opportunity, and the entrepreneurial process.

Several researchers have studied the processes and the driving forces of realizing opportunities. Ajzen [5] proposed the 'theory of planned behavior' that predicts the human behavior with his or her intention. Hamel and Prahalad [17] suggested the concept of 'strategic intent' or an obsession to stretch goals, as a source of winning in the world market. Shepherd and Kruguer [32] mentioned 'entrepreneurial intention' that can be used in predicting the intention to found a venture. These theories have served as theoretical foundations for the new concept of 'entrepreneurial intent,' but have limitations in explaining the emergent process of realizing entrepreneurial opportunities.

Although a strong entrepreneurial intent appears to be largely accepted as a central driving force in the entrepreneurial process [25], a proper theory to account for this is to be devised. Entrepreneurial intent is likely to be seen as an extreme case of motivation. This type of motivation enables individual entrepreneurs to make entrepreneurial process resulting in opportunity realization, which can be verified by studies about relations among individuals, process and results [31]. To put it differently, some explorations on the connection between entrepreneurs and opportunities such as [40] are expected to show how individual level of behaviors affects industrial level of achievements [26].

Entrepreneurial journey emerging from entrepreneurial intent is in specific a procedure of opportunity realization through the combination of resources. In this regard, several theories are deserved to be mentioned: 'new combination' [28], 'dynamic capability' [35], 'resource-based view' [8], and 'innovation journey' [38]. However, the 'new combination' theory is concerned solely with the big notion of innovation and neglects some details, whereas the 'dynamic capability' theory appears to supply an introductory level of explanation on its three components. The 'resourcebased view' is unable to evaluate the value, rarity, inimitability and difficulty of substitution of nonexistent resource combination. It is general that the extent of possessing resources at the present cannot guarantee the opportunity realization in the future. Especially because of the 'liability of newness' [33], the resources of new ventures tend to be much poorer than those of other corporations. The theory of innovation journey provided an excellent description of the course of innovations through alternating 'convergent behavior' and 'divergent behavior' [38].

In the mean time, resource-based view is able to overcome its limits if it adopts the notions such as potential resources, capabilities to combine resources and the directivity to connect them. It is true that this kind of approach is attempted by several authors through complementing the entrepreneurial capability [2][3][4], but it is also true that in spite of the complementing efforts the theory cannot avoid the criticism that it regards all the internal elements like corporate-internal procedures or potential parts as company resources.

Entrepreneurial process that discovers and realizes the chance in the growth of a venture is seen as an insecure process of 'trial and error' to search and combine dispersed potential values. The root of this view is that the knowledge needed in order to realize new values are dispersed and that the potentiality of the values does not yet reveal itself. Since knowledge in need remains dispersed and scattered, its possessors happen to be unable to appreciate its value [18] while it can serve as a basis to detect a new opportunity [30]. Therefore for the purpose of finding out a new opportunity by using the method of bricolage which utilizes scarce knowledge and seemingly unrelated resources, the entrepreneurs pursue brand-new combinations by maximizing their resources and means [6][7]. In this sense, entrepreneurs can be called 'bricoleur' who establishes new connections and makes new combinations. In other words, innovation is achieved by new combinations of given resources [28], and it is the role of 'Arbitrageur' that enables the new combinations [21]. Entrepreneurs as an arbitrageur can create new values only when they play a role as a 'structural hole' to connect groups that have different resources and demands in their networks, whichever are already formed or on the way of forming [12]. The entire process proceeds in the way of bootstrapping and trial and error, and requires entrepreneurs to utilize their available resources maximally but economically and to focus the resources on the entrepreneurial project [15]. In the meanwhile entrepreneurial actions are launched with specific intentions under uncertain circumstances. In this vein, entrepreneurial process being made under unsecured situations deserves to be referred to as an innovation journey as Van de Ven has called [36][38], and also as entrepreneurial journey for the entrepreneurs to provide organizational resources as well as financial ones, and to construct some functions in need.

Building a theory about a complicated and dynamic phenomenon implies the maximal use of elements in the existing theories to develop a new concept and apply the borrowed notions into the new theory. Given that the new theory building is considered as a sort of innovation, new combination of knowledge can be made not by adherence to the preexisting procedure or orthodox methods but by deviation from them [38].

\section{RESEARCH FRAMEWORK AND METHODS}

We conducted the theory through integrating both case study according to inductive approach and literature review according to deductive approach. Although there are not the formal periods in venture growth, we need understanding of internal process. This suggests that we should conduct case 
study rather than literature review, indicating that we need integration between two approaches for developing theory of venture growth. Based on actual data, we have made concepts and categories and developed a theory through the 'grounded theory approach' with logical backgrounds [34], as shown in Figure 1.

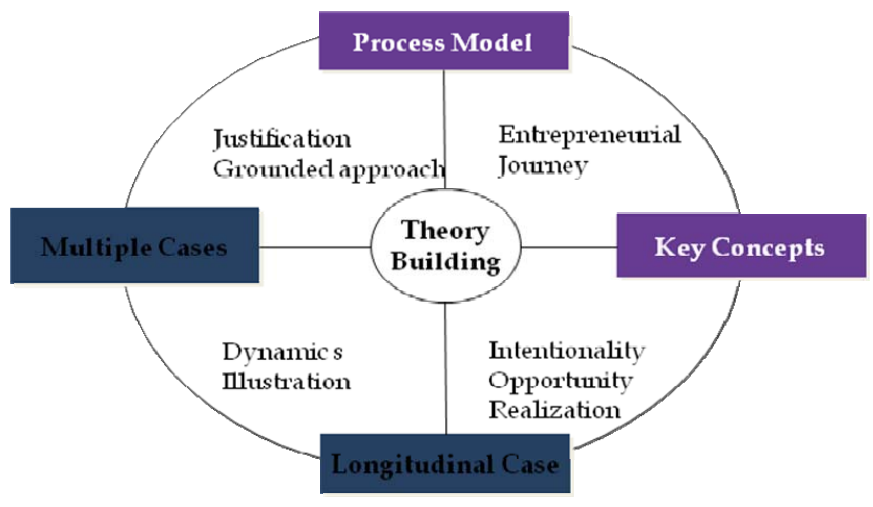

Figure1. Theory Building Process

Following Eisenhardt [16], we have conducted interviews and collected data, and developed a theory based on raw data, open coding, axial coding, and selective coding [34].
Grounded theory itself makes the paradigm model after collecting data, categorizing (open coding) and characterizing six factors in the theoretical framework (axial coding). The paradigm model consists of cause, phenomenon, contextual condition, intervening condition, interaction, and consequence. However, explaining all the problems with six relationships can make some problems such as interrelations between variables.

This study followed the typical procedure in data collection and case studies, as suggested by Eisenhardt [16] and Yin [41]. We collected data from archive, books, articles, in-depth interviews and field experiences. We conducted open coding according to raw data, axial coding for constructing categorical relation, and selective coding for research model [34]. Categorization uses core variables addressing an entrepreneur, opportunity, entrepreneurial activity and venture growth, indicating that we develop a theory based on multilayered aspects considering entrepreneurial intent, entrepreneurial activity, and opportunity realization.

Axial coding could be an approach for developing of the grounded theory. However, the reality could have diverse theoretical possibility. Figure 2 shows the research model addressing contextual and intervening conditions based on axial coding.

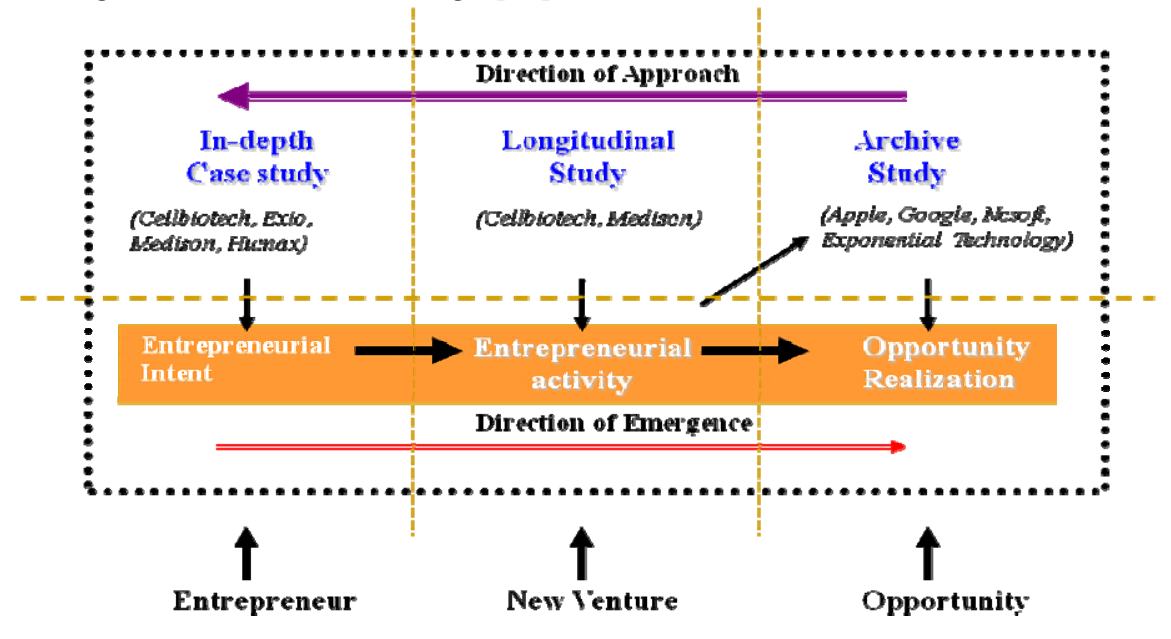

Figure 2. Research Framework: Addressing Emergence

Entrepreneurism could be multi-level. Case study could be useful research methodology for mechanism and causality of emergent phenomenon [9]. Also it could enhance possibility of finding causality of emergent phenomenon. Prior research for entrepreneurism used case study and descriptive study rather than survey. We collect data at the levels of market, company, resource, and entrepreneur. New venture cases used in theory building are Cellbiotech, Medison, Humax, NC Soft, Exio Communications, Exponential Technology, Apple and Google.

We document entrepreneurial activity based on technology, market, organization and finance as research tool for explaining entrepreneurial journey. Problems during the journey for realizing opportunity show the main events such as technology, market, organization and finance for solving problems in longitudinal perspectives. These events could be internal activity and also be through interrelation between external networks.

Entrepreneur, opportunity and their relation are main subject for entrepreneurism [30][31]. Shane and Venkataraman [30] are looking inside the 'black box' and are difficult to study because of uncertainty. We believe that the study to examine internal mechanism of venture growth is necessary to solve and could be valuable to conduct. The research of entrepreneurial journey should use longitudinal approach [37]. We could explain the entrepreneurial journey 


\section{PICMET 2008 Proceedings, 27-31 July, Cape Town, South Africa (c) 2008 PICMET}

for realization of opportunity by the events and results during the process of new venture [39]. Venture growth could be realized by solving the problems during the journey [10] for entrepreneurial intent [20].

\section{A THEORY OF ENTREPRENEURIAL JOURNEY}

\section{A. Entrepreneurial Journey of New Venture Growth}

To grow new ventures should solve lots of problems. The problems which a venture gets to face are sometimes internal and sometimes external. They occur in the middle of realizing opportunities, and what is first and foremost important in the venture's growth is to make endeavor to gain the competence to realize some potential entrepreneurial opportunities.

Problems which a venture confronts in the course of its growth take place either consecutively or simultaneously. And it is general that they happen dependently. Taking into account of an example of Cellbiotech, when they created their business, they needed money to develop lactic acid bacteria powder, so they tried to get the investment from the local government. When getting money, they had to use their network and recruit qualified researchers. Even after they succeeded in developing the core technique, they needed more money for mass cultivation of lactic acid bacteria and for construction of factories, and had to begin with market creating. This is what Cellbiotech did from the point of technique development to market building when it faced problems happening consecutively. We also confront difficulties consecutively in the process of discovering and fulfilling market opportunities.

Among the problems, some are predictable, but some are unpredictable and uncertain in the sense of their multiple sources. There exist apparently insolvable problems and solvable but hard ones. Technical problems may be much easier to handle than, for instance, financial ones. On the basis of the analytical framework mentioned above, Figure 3 displays core events in four areas during the growth of Medison and its relationships with outer related institutions. What is peculiar about Medison is the balanced problemsolving procedures in four areas. These are in sharp contrast with problem-solving patterns in most other corporations, in which an asymmetry comes about in the market area or the financial area at the critical moment of their growth, bringing out a dramatic settlement.

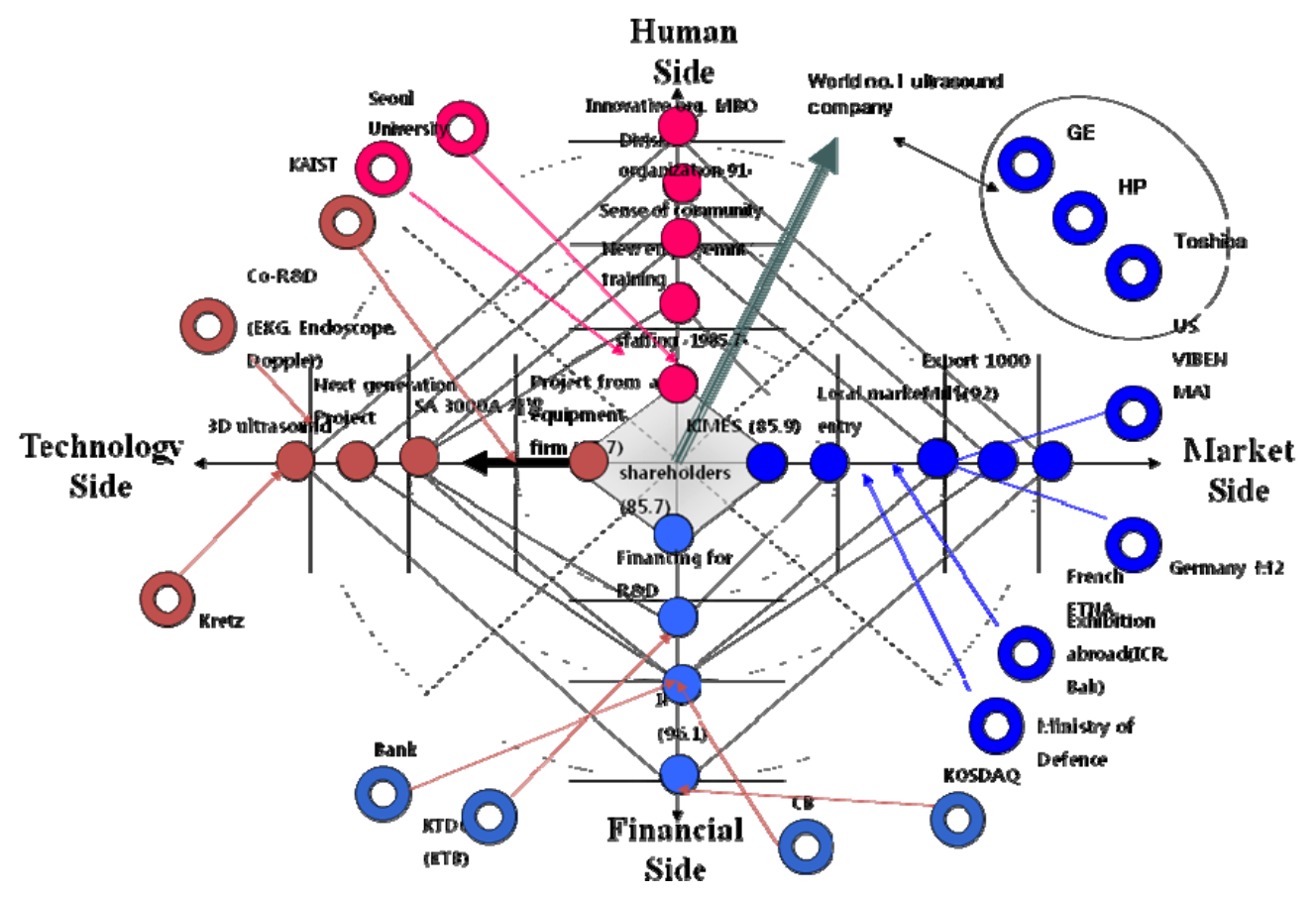

Figure 3. Balanced Map of the Entrepreneurial Process: Medison Case

In actual entrepreneurial actions to solve the facing problems are performed simultaneously in several bases in economic system. This paper embraces the view of Cha and Bae [13] that includes four bases: management, technology, market, and financial. In the management base, experts are recruited, educated, and organized. Meanwhile in the technology base, technologies are acquired, and new products are developed. In the market base, entrepreneurs seek customers, inquire into their needs, construct relationships, make efforts to observe the movement of market, and convey the values that opportunities require. In the financial base, they look for investors, raise money, and sometimes make an investment, which differs according to ventures' financial resource and to the condition of the capital market. All of these entrepreneurial actions which occur in four areas are ultimately for the purpose of solving problems each venture confronts. They are classified further into by the following criteria. 


\section{PICMET 2008 Proceedings, 27-31 July, Cape Town, South Africa (c) 2008 PICMET}

(1) Is the problem inner or outer one?

(2) Is the problem inevitable in the course of venture growth, or occasional?

Problems occur in market base and technology base are mainly dominant ones which happen consecutively, and they interact with each other until they are resolved. Put it simply, the matters such as product development, release of new products, equipment of system to enable mass supply, and market expansion are both consecutive and dominant. But there also are occasional problems in market and technology base, for instance, difficulties of market understanding, new entrants, technological trial and error, cooperate development or consortium management. The dominant problems in management and financial base are structuring to support innovative processes in market and technology base, and fundraising. As occasional difficulties in these bases, internal conflicts or problems in cash flow deserve to be mentioned.

It was essential for Cellbiotech to raise governmental funds for technology development. In spite of inferiorities with respect to technology, money, and human resources, Cellbiotech convinced the investigators of their success by means of showing their desperate intent and firm belief of their lactic acid bacteria cultivating and coating skills. Their desperate, persistent intent persuaded investors to trust them despite their insecure, uncertain conditions. In some other sense, the internal driving force helped Humax to focus the market opportunity. After the failure of the first product, Humax realized that what is the most important thing in the market is not the best technology that they once pursued in the laboratory as academic researchers, but what consumers want in the real. As a result Humax is now a company whose will to focus on the market opportunities is much more intense than any other corporations.

IDIS is another example which shows strong entrepreneurial intent draws outer resources, fills the resource gap and facilitates recognition of market opportunities. Consisting of electric engineering doctorates from KAIST, IDIS discovered the possibility of merchandizing digital video recorder (DVR), and strived to develop DVR. Their strong intent attracted other researchers, made them discard secure positions and plunged themselves into the insecure world of venture.

Entrepreneurial intent plays an important role in searching necessary resources and supplying, which can be called a most reinterpreted meaning of absorptive capacity. On the basis of this capacity entrepreneurs take a part of attractor who wins over new resources. Opportunities in business can be obtained by constantly overcoming obstacles, and they reveal themselves as growth of ventures in the realm of dynamics. Although potentialities of opportunity realization always suffer from lots of visible obstacles and outer forces, the internal driving force firmly leads entrepreneurs to seek entrepreneurial opportunities. The course of combination of new resources is directed to new ventures from all four areas, and is possible through interconnection of them. The process and result of resource combination can vary depending on the circumstances. Thus entrepreneurial process should be analyzed under multiple conditions as well as in a longitudinal view [37]. Silicon Valley where technological opportunities and entrepreneurial capitals are abundant, and where new information and workforce are exchanged actively, for example, makes a difference from other business circumstances [27].

Although situated in the same region, entrepreneurial processes which each venture experiences can differ distinctively due to the entrepreneurial situation it is exposed to. Exio Communications and Exponential Technology are taken to be good instances. Starting businesses in Silicon Valley, Exio Communications which entered into the mobile communication market with a home-made CDMA technology had difficulties in raising funds and recruiting experts because of lack of time and poor local networks. But after successfully contracting with Sprint, it finally got the offer from Cisco Systems. On the other hand, Exponential Technology developed a state-of-the-art microprocessor with the combination of experts from Stanford University and investments form some venture capitals, but only to fail, because of Apples' withdrawal of the original decision to transact with the company. The former represents the case where entrepreneurial efforts overcame unfavorable conditions especially in terms of resources, and the latter the case where entrepreneurial journey ended in tragedy even in favorable resource conditions, because of uncertainty of the market.

Core role of entrepreneurial intent is getting over the obstacles in the journey of entrepreneur by utilizing newly combined resources and realize opportunities. Entrepreneurial intent is a mindset to discover and realize new values. In other words, it is the application of strategic intent [17] into entrepreneurial mindset [22]. Strategic intent means a strong adhesion to victory in the long term competition [17], and entrepreneurial mindset means an orientation to opportunities. Entrepreneurial intent contains both of the drive and the directivity. Entrepreneurial intent is different from the entrepreneurial orientation and strategic intent for its motivational nature toward opportunity. To define new concepts, this study follows the integrating approach and uses a $2 \times 2$ matrix. Table 1 explains the concept of entrepreneurial intent by using two axes of [opportunity-centric vs. resourcecentric] and [behavioral (latent) vs. motivational (committed)]. Entrepreneurial intents can be understood as entrepreneurial (opportunity-driven) approaches toward stretched (strategic-focus) goals. 


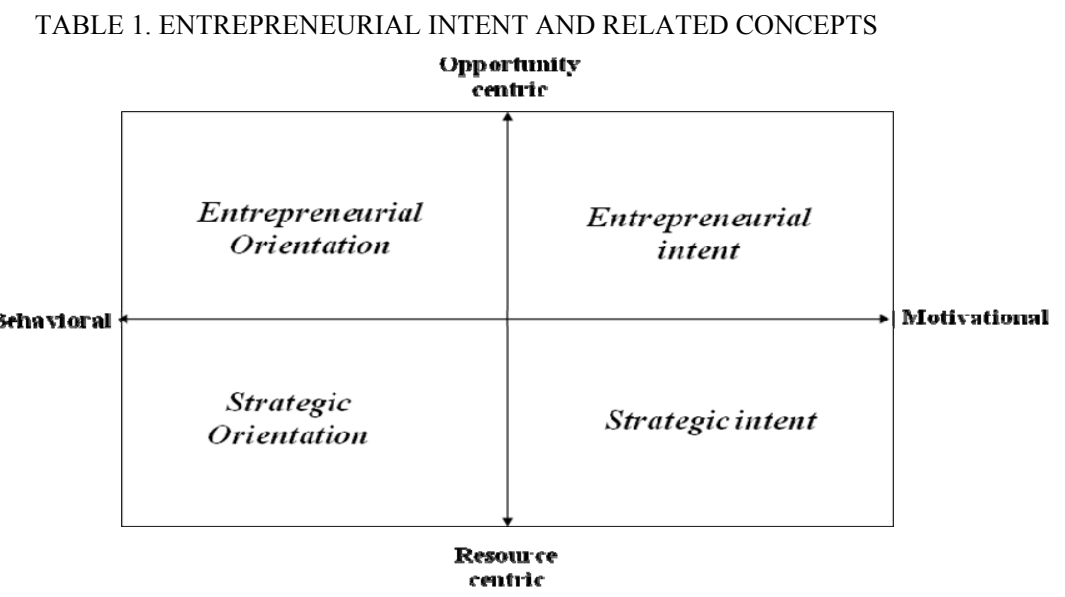

Entrepreneurial intent is the mental force that realizes the value of a new business opportunity. It is in the intersection of strategic intent [17] and entrepreneurial mind-set [22]. Strategic intent is the part in which goals are set to establish a new position in the market or win against the competition. Strategic intent is a more sharpened and desperate state of mind to develop competitive business. Past research defines strategic intent as strong obsession with success and victory in the long term [17]. Strategic intent is the intent of the entire organization to win over rivals, if there are any. Entrepreneurial intent, on the other hand, is the focus not on competitors but on opportunity itself. It begins from the individual and is extended to the founding group. Entrepreneurial intent is more relevant in creating new market.
These two sides are displayed inter-connectively. An entrepreneurial mind-set without a clear directivity has no clear focus on activities. What is the most entrepreneurial element in the strategic research? As it is said in Competing for the Future, the firms that develop new core competencies based on strategic intent become the front-runner of the future [17]. This can be applied to both new and existing firms. Strategic intent sources energy for firms to move forwards toward a goal.

From a number of observed cases there are two common aspects of entrepreneurial intent that has two dimensions of directivity and drive. Directivity channels the entrepreneurial action, drive of intent continuing the action and the synergy of two dimension concentrate all the effort and energy. Table 2 illustrates the $3 \mathrm{C}$ effects in four dimensions.

TABLE 2. 3C EFFECTS OF ENTREPRENEURIAL INTENT IN THE JOURNEY

\begin{tabular}{|l|l|l|l|l|}
\hline \multicolumn{1}{c}{$\begin{array}{c}\text { Effects on } \\
\text { actions }\end{array}$} & \multicolumn{1}{|c|}{ Market } & \multicolumn{1}{|c|}{ Technology } & Organization & Finance \\
\hline Channeling & $\begin{array}{l}\text {-Market } \\
\text { orienting (e) }\end{array}$ & $\begin{array}{l}\text {-Technology } \\
\text { orienting }\end{array}$ & $\begin{array}{l}\text {-Attaining } \\
\text { participations (e) }\end{array}$ & •Bootstrapping \\
\hline Concentrating & $\begin{array}{l}\text {-Committing } \\
\text { on customers' } \\
\text { problem (e) }\end{array}$ & $\begin{array}{l}\text {-Intensive efforts } \\
\text { on technological } \\
\text { problem (i) }\end{array}$ & $\begin{array}{l}\text {-Focusing on } \\
\text { Coherency (i) }\end{array}$ & $\begin{array}{l}\text {-Saving and } \\
\text { Investing (i) }\end{array}$ \\
\hline Continuing & $\begin{array}{l}\text {-Resolving } \\
\text { customers } \\
\text { problems (i) }\end{array}$ & $\begin{array}{l}\text {-Searching and } \\
\text { discovering the } \\
\text { solutions }\end{array}$ & $\begin{array}{l}\text {-Recruiting key } \\
\text { persons (e) }\end{array}$ & $\begin{array}{l}\text {-Persuading } \\
\text { capitalist (e) }\end{array}$ \\
\hline
\end{tabular}

B. Opportunity Realization: Emergence from Entrepreneurial Intent

Along the process of appearance, growth and disappearance of opportunity, an entrepreneur finds an unrealized opportunity and exerts entrepreneurial effort in order to accomplish the opportunity. Opportunity is the potential to provide to consumers new value through services or products. An entrepreneur finds several opportunities, and embarks on the mission by investing and developing necessary abilities. By offering consumers the value at their required standards, the opportunity is realized. Through differentiation, the entrepreneur can occupy a position in the market while creating a barrier of entry. Unfulfilled demand and scattered resources with uncertain value meet to realize business opportunity.

A realized opportunity affords validity and a position in the market, but sustaining a competitive position is almost impossible [14]. New entrants can enter the market even after the opportunity is realized. Especially in situations where the market grows to a big size, large firms and multinational 
companies enter the market. In the situation of price competition through economies of scale causes the new venture to lose its competitive position and to differentiate by choosing a specific domain in the market. Of course enriched resource environments such as Silicon Valley, small venture firms can grow to be large companies like HP or Apple. However in the cases of Reigncom and VK mobile, the proliferation of the MP3 player and cellular phone markets to the entire world intensified competition, and they could not sustain their position after opportunity realization. The entrepreneurial journey does not successfully complete with the realization of opportunity. The journey can only continue by careful preparation with new circumstances. This study focuses on the process of finding and realizing opportunity. Figure 4 explains the process of realization between Reigncom and its competitor, Apple.

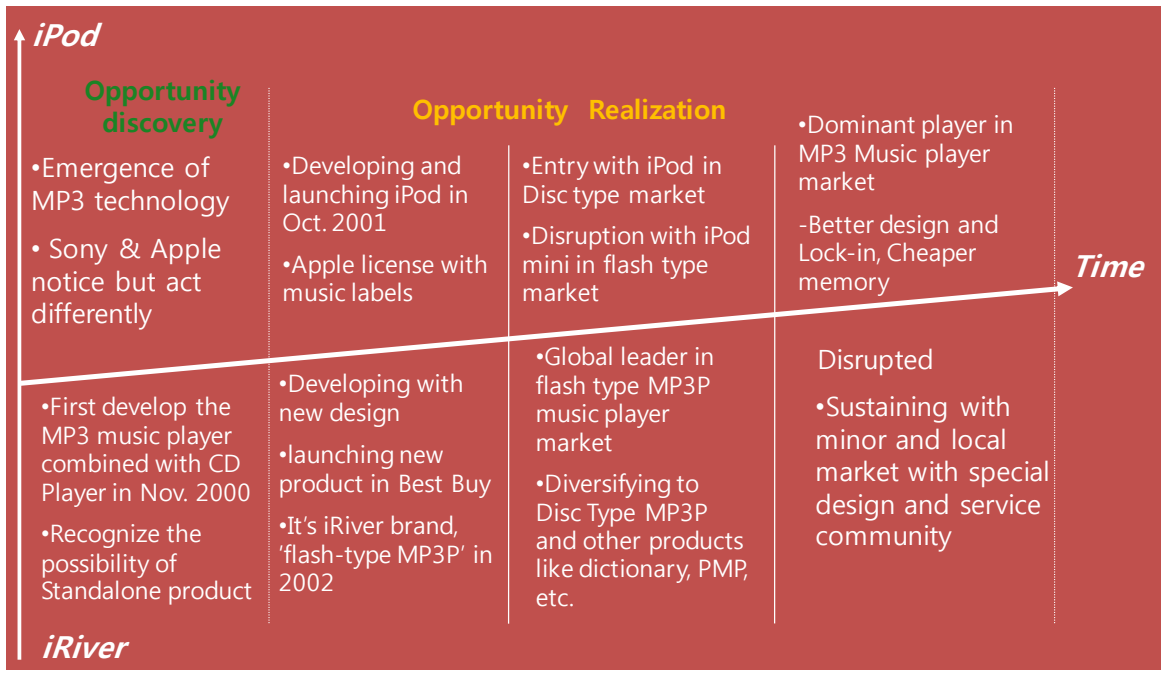

Figure 4. Opportunity Realization: Reigncom vs. Apple

New ventures grow through the process of opportunity realization. Realizing opportunity signifies continuous process of finding the required resources and fusing new value in four areas. In order to realize the opportunity, building a system that continuously provides customer satisfaction is necessary. Actual capability and potential capability function during the entrepreneurial process, but most important of all is the absorptive capacity to build new capability [42].

To realize opportunity, the entrepreneur must provide value to consumers; the kind that they want. Deeply observing opportunity, one can see when the possibility of realization began and its composition. The entrepreneurial journey can complete successfully if the gap between the new venture and opportunity can be filled.

In order to provide to consumers the value that they want, the entrepreneur needs to have new resources. There are few activities required to make new resources, for example, development of a new technology, finding investors or finding the latent and potential consumer needs.

These entrepreneurial activities rise from entrepreneurial intent. When all conditions are identical, the entrepreneur with the stronger intent will attempt more and is more likely to find the solution. However, having strong intent does not assure success.

In the case of Cell-biotech, the founder who studied microbiology showed much motivation in sales and research during his employment at a large firm. His entrepreneurial intent was formed while studying in Denmark. While participating at a joint study at Christenhansen, the world famous manufacturer of lactic bacteria, he realized that there existed a terrific opportunity in the market. Despites the ups and downs of establishing his business, the dramatic opportunity came when he received funding going up against a large firm. He needed the funds to start his business and the panic of realizing there was no other way, he devoted his life to research. In the end his efforts won the favor of the investors and he was able to receive funding for developing the technology. Technology development and funding were the largest of his problems; he was able to form a research center from the funds from Gyonggi Province. In 1996, Cellbiotech becomes the fifth in the world to develop lactic acid bacteria ("powder technology"). After the establishment of the first factory, two years of joint research with Hallym University enabled them to develop ten different kinds of lactic acid bacteria at half the price of imported lactic acid bacteria. This is the initial realization of opportunity.

LAB industry, worldwide, was quite large and the consecutive task required developing the coating technology that enables the bacteria to live a longer period of time. As the business enters into the initial growth stage, quality and lack of funds create problems. They resolve funding problem through investments from KTV, employees spend countless nights in the factory to fix quality problems. The founder learns more about managerial finance, because they were constantly up against liquidity problems. The biggest 


\section{PICMET 2008 Proceedings, 27-31 July, Cape Town, South Africa (c) 2008 PICMET}

liquidity risk came during the Asian Financial Crisis, they had to sell all there assets and get help from people near them. When they build their second factory, the focus is on supplying their own complete products from start to finish. At this time 18 of the 22 employees were research personnel. Overcoming this crisis, they were declared as a venture company and were able to enter into their latent growth stage.

Through strategic cooperation they were able to guarantee a sales network, and the firm grows to the size of 60 employees. The firm declares to export the products. They were finally able to step into the global market as they had wished. This is when the entire company as whole braced themselves and formed collective intent. They formed a strategic alliance with Samsung Corporation and enter the European market, and by the year 2002 they were able to export to 50 large firms in 10 different companies. In 2003, the company falls into maturity and was able to IPO. They developed their own brand "Bodytune" and supply to convenient stores and etc. The design or the promotion was not carried out very well, but holds a strong position in the nutraceutical product market.

The entrepreneurial intent and activities are evident in the case of Cell-biotech. The founder leaves and embarks upon his entrepreneurial journey as soon as he finds his intent. He expends all his effort and into developing the technology and finding funding. All his experience and intent is on focused on developing lactic acid bacteria. In order to supply the product in large amounts, there were continuous problems of finding funding for research and his efforts were focused on finances as well as development and operations. It is emergent process from underlying motivation to actions and resources. Table 3 is the outcome of multilayered emergent process of opportunity realization that is transformed from a scratch.

\section{TABLE 3. EMERGENCE THROUGH FOUR INNER LAYERS: CELLBIOTECH}

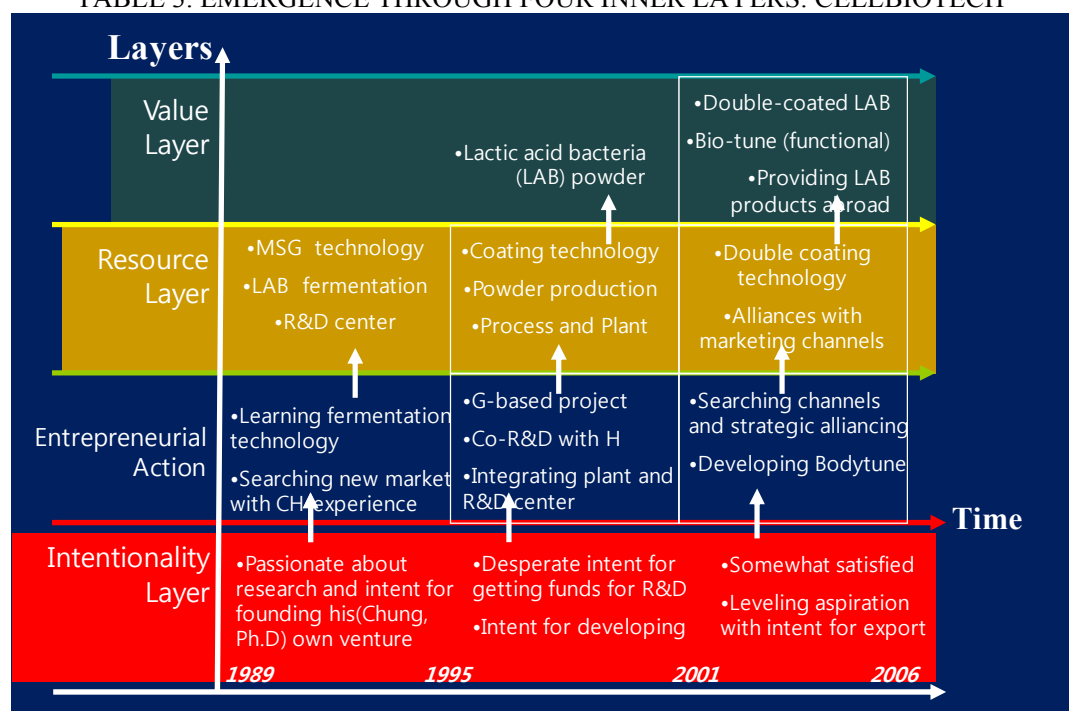

The process of realizing opportunity, as in the case of Cell-biotech, entrepreneurial intent, activities, resource and value the four gaps are filled. Intent fulfilled before establishment pointed the direction, and through conversion, concentration and continuity of activities was able to resolve the differences existing in resources. The most important was the development of powder and coating technology. The financial gap remained a problem for a long period of time, even through their growth stages they faced liquidity problems. They had no distribution network, and this was hard for them to develop on their own. Through cooperation with large companies that have existing distribution channels, they were able to fill this gap. When the company began to do well and win awards, the tension loosened within the organization. They declare to enter the global market, which was a long time vision of the organization, and they were able to solidify the intent of the entire organization. They were able to renew the organization by creating the capability to trade with global firms and building new processes, thereby continuously realizing opportunity.

The coming together of activities and resources is his previous education of microbiology and experience in sales and research in this area. By studying abroad he was able to come into contact with information about the wider market. With new information and knowledge, the intent was instilled and pointed the direction towards the lactic acid bacteria market. This intent enabled him to be the fifth in the world to develop powder technology and the world's first doublecoating technology. Research capability is built through the countless focus and effort into research. The manufacturing method or coating method was discovered through countless efforts in trial and error, it was the result of serendipity and effort. It was not only their internal capability but through joint research with Hallym University, and the distribution attained from 50 or more companies.

Between resource and value there is a gap which signifies that the existing resources are unable to provide value to the 


\section{PICMET 2008 Proceedings, 27-31 July, Cape Town, South Africa (c) 2008 PICMET}

market demand. The founder first discovered the opportunity while at Christianhansen, and after 10 years of hard effort he was able to build the capability of mass producing lactic acid that can be preserved over time. He already had the knowledge from experience and studies abroad, and all he had to do was to focus down the path. Of course funding, manufacturing, sales, research and other factors were obstacles to overcome; these obstacles strengthened the capability.

When there is a competitor that provides better value to customers the chances of realizing opportunity is relatively smaller. To realize opportunity, one must attain validity and positions itself in the market. Competition jeopardizes this position. If the value provided is more competitive than that of the competitor's then a better position in the market will be attained and the potential market can be attained.

The gap-filling process consists of motivation, innovation and fulfillment. The case of Cell-biotech, we saw the intent behind the story; this process is what is called 'visioning.' Motivation, innovation and fulfillment are what are called 'acting' of the process. Visioning forms an intent, but 'acting' allows the intent to show. When the opportunity is realized, there must be a new and different direction and the formation processes accompany in order to sustain an entrepreneurial activity.

The entrepreneur declares the vision and develops the seed technology, forms an organization with close allies and bootstraps the necessary funding. Through visioning the entrepreneurial intent drives the new venture's innovation processes and helps to build the basic organization and helps to find investments. The value arising from innovation is sold in the market and gains market power, and further attempts to acquire technology is made. This is done through building research centers or partnerships, and in the finance area innovation creates profit. Thus through this process to fulfill the needs of partners in the industry and consumers, the achievements will enhance its validity as a new entity in the economy and the standard of new technology. It will form the organization and distribution channels, which will lead for the venture to enlist in the market. Then the venture will reach a position in which it can gain financing from investors. It is highly important in the entrepreneurial process to group resources with potential to valuable forms along the way. The difference between the start and end is the gap of resources. If the market problem is resolved then the entrepreneur has the right product and right technology. Organization and finances are what innovation relies upon.

Based on the case studies and the theoretical bases, the entrepreneurial process is carried out along three phases. First is the drive which helps to search for directivity. The perception of opportunities enables to resolve the cognition gap thus form an entrepreneurial intent. Second is based on the entrepreneur's various experiences, knowledge and networks that fuel the entrepreneurial actions. In this stage, motivation gap is filled and the entrepreneur heads, concentrates and continues to realize opportunity. In the last phase, the limited resources that the entrepreneur possesses must be fused with outside resources successfully to resolve the resource gap and eventually realize the opportunity.

\section{DISCUSSION AND CONCLUSION}

Entrepreneurial journey begins with new entrepreneurial intent. Intentionality in innovation and entrepreneurship should be explored because it is the focal point of new business and organization emergence [1][10][19]. Moreover, it can be the key elements of entrepreneurial capability of resource combining for opportunity under uncertainty [3][4]. Entrepreneurial journey consists of prepared activity as well as improvised actions of bricolage [6][7]. The outcome of the process emerges in uncertain and risky condition [36][38]. We can see the different journeys of opportunity realization in different places [27], network [12], and institution [1][29]. Key aspect of the process is the 'make-it-happen' intentionality. Channeling, concentrating, and continuing of entrepreneurial activities are the critical effects in the process of emergence from intent to realization.

\section{REFERENCES}

[1] Aldrich, H. E. (1999), Organization Evolving, London: Sage Publications.

[2] Alvarez, S.A., and J.B. Barney (2000), "Entrepreneurial capabilities: A resource-based view," In G. D. Meyer and K. A. Sheppard (Eds.), Entrepreneurship as Strategy: Competing on the Entrepreneurial Edge (pp. 63-82). Thousand Oaks: Sage Publications.

[3] Alvarez S.A. and J.B. Barney (2005), "How Do Entrepreneurs Organize Firms Under Conditions of Uncertainty?" Journal of Management, 31(5): pp.776 - 793.

[4] Alvarez S.A. and L.W. Busenitz (2001), "The Entrepreneurship of Resource-based Theory," Journal of Management, Vol. 27, pp.755-775.

[5] Ajzen, I. (1985), "From Intentions to Actions: A Theory of Planned Behavior. In J. Kuhl \& J. Beckman (Eds.), Action Control: From Cognition to Behavior, 11-39. Berlin: Springer-Verlag.

[6] Baker, A.M. and D. Eesley (2003), "Improvising Firms: Bricolage, Retrospective Interpretation and Improvisational Competencies in the Founding Process," Research Policy, Vol. 32, pp. 255-276.

[7] Baker, A.M. and R.E. Nelson (2005) "Creating Something from Nothing: Resource Construction through Entrepreneurial Bricolage," Administrative Science Quarterly, 50, pp. 329-366.

[8] Barney, J. (1991), "Firm Resources and Sustained Competitive Advantage," Journal of Management, 17(1), pp.99-120.

[9] Bhaskar, Roy (1975), A Realist Theory of Science, London: Verso.

[10] Bird, B. (1988), "Implementing Entrepreneurial Ideas: The Case for Intention," Academy of Management Review, Vol.13, No.3, pp.442-453.

[11] Bloodgood, J.M., H.J. Sapienza, and A.L. Carsrud, A. L. (1995). "The Dynamics of New Business Start-ups: Person, Context, and Process," in Advances in Entrepreneurship, Firm Emergence, and Growth, 2, pp.123-144.

[12] Burt, R.S. (1992), Structural Holes: The Social Structure of Competition, Cambridge, MA: Harvard Business Press.

[13] Cha, Min-Seok and Zong-Tae Bae (2003), "Toward the Theory of Venture Growth: A Driving Force and Four Growth Bases," BKREC (Babson-Kauffman Foundation Entrepreneurship Research Conference), Babson Park, MA, USA, June 4th-8th.

[14] Christensen, C.M. (2003), The Innovator's Solution: Creating and Sustaining Successful Growth, Boston: Harvard Business School.

[15] Ebben J. and A. Johnson. (2006), "Bootstrapping in Small Firms: An Empirical Analysis of Change over Time," Journal of Business Venturing, 21(6), pp.851-865. 


\section{PICMET 2008 Proceedings, 27-31 July, Cape Town, South Africa (c) 2008 PICMET}

[16] Eisenhardt, K.M. (1989), "Building Theories from Case Study Research," Academy of Management Review, Vol. 14, No. 4, pp.532550.

[17] Hamel, G. and C.K. Prahalad (1989), "Strategic Intent," Harvard Business Review, 67(3), pp.63-76.

[18] Hayek, F.A. (1945), "The Use of Knowledge in Society," American Economic Review, XXXV (4), September, pp.519-30.

[19] Katz, J. and W.B. Gartner (1988), "Properties of Emerging Organizations," Academy of Management Review, Vol. 13, No. 3, pp.429-441.

[20] Kazanjian, R.K. (1988), "Relation of Dominant Problems to Stages of Growth in Technology-Based New Ventures," Academy of Management Journal, Vol.31, No.2, pp.257 279.

[21] Kirzner, I.M. (1997), "Entrepreneurial Discovery and the Competitive Market Process: An Austrian Approach," Journal of Economic Literature, Vol.35, pp.60-85.

[22] Kuratko, D.F. and R.M. Hodgetts (2007), Entrepreneurship: Theory, Process, Practice, Mason: Thomson South-Western.

[23] Mitchell, R.K., L.W. Busenitz, B. Bird, C.M. Gaglio, J.S. McMullen, E.A. Morse, and J.B. Smith (2007), "The Central Question in Entrepreneurial Cognition Research," Entrepreneurship Theory and Practice, Vol.31, No.1, pp.1-27.

[24] Naffiziger D. (1995), "Entrepreneurship: A Person Based Theory Approach," Advances in Entrepreneurship - Firm Emergence, and Growth, 2, pp. 21-50.

[25] Norwood T. (2007), "Tiffany Norwood Speaks To eClips," eClips, Cornell University, http://cornell-eclips.blogspot.com/2007/10/tiffanynorwood-speaks-to-eclips.html.

[26] Phan, P.H. (2004), "Entrepreneurship Theory: Possibilities and Future Directions," Journal of Business Venturing, Vol.19, pp.617-620.

[27] Saxenian, A. (1994), Regional Advantage: Culture and Competition in Silicon Valley and Route 128, Cambridge, MA: Harvard Business Press.

[28] Schumpeter, J. (1942). Capitalism, Socialism, and Democracy. New York: Harper \& Row.

[29] Scott, W.R. (1987), "The Adolescence of Institutional Theory," Administrative Science Quarterly, 32, 493-511.
[30] Shane, S. and S. Venkataraman (2000), "The Promise of Entrepreneurship as a Field of Research," Academy of Management Review, Vol.25, No.1, pp.217-226.

[31] Shaver, K.G. and L.R. Scott (1991), "Person, Process, Choice: The Psychology of New Venture Creation," Entrepreneurship Theory and Practice, Vol.16, pp.23-45.

[32] Shepherd, D. A. and N.F. Krueger (2002), "Intentions-Based Model of Entrepreneurial Teams Social Cognition," Entrepreneurship: Theory and Practice, 167-184.

[33] Stinchcombe, A.L. (1965), "Social Structure and Organizations," in March, J.G. (Ed.), Handbook of Organizations, Chapter 4, Chicago: Rand McNally \& Company, pp.142-193.

[34] Strauss, A. and J. Corbin (1990), Basics of Qualitative Research: Grounded Theory Procedures and Techniques, Sage Publications.

[35] Teece, D. J., G. Pisano, and A. Shuen (1997), "Dynamic Capabilities and Strategic Management," Strategic Management Journal, Vol.18, No.7, pp.509-533.

[36] Van de Ven, A.H. (1986), "Central Problems in the Management of Innovation," Management Science, 32(5), 590-607.

[37] Van de Ven, A.H. (1992), "Longitudinal Methods for Studying the Process of Entrepreneurship," In: Sexton, D.L. and Kasarda, J.D. (Eds.), The State of the Art Entrepreneurship, PWS-Kent, Boston.

[38] Van de Ven. A.H., D.E. Polley, R. Garud and S. Venkataraman (1999), The Innovation Journey, Oxford: New York.

[39] Van de Ven, A.H. and R.M. Engleman (2004), "Event- and Outcomedriven Explanations of Entrepreneurship," Journal of Business Venturing, Vol.19, pp.343-358.

[40] Venkataraman, S (1997), "The Distinctive Domain of Entrepreneurship Research: An Editor's Perspective,” In: Katz, J.A. and R.H. Brockhaus (Eds.) Advances in Entrepreneurship, Firm Emergence, and Growth, Vol.3, JAI, Greenwich, CT.

[41] Yin, R.K. (1989), Case Study Research: Design and Methods, Sage Publications.

[42] Zahra, S. and G. George (2002), "Absorptive Capacity: A Review, Reconceptualization, and Extension," Academy of Management Review, Vol. 27, No. 2, pp.185-203. 